\title{
|ESTERILIZAÇÃO DE ALIMENTOS POR MICROONDAS PARA PACIENTES RECEPTORES DE TRANSPLANTE DE MEDULA
}

\author{
Luciola de Sales Seabra Matos*
}

\begin{abstract}
RESUMO - Receptores de transplante de medula apresentam inúmeros problemas gastrointestinais que interferem com uma adequada ingestão oral. Estudos prévios mostram que o ambiente com fluxo laminar, dieta estéril, descontaminação oral com antibióticos e limpeza da pele são fatores significantes na prevenção da infecção. A literatura recomenda a esterilização dos alimentos por autoclagem, irradiação cu forno. Nesse trabalho propõe-se a esterilização por microondas, por ser um processo rápido, seguro e não alterar o aspecto e sabor dos alimentos.
\end{abstract}

\begin{abstract}
Marrow transplant recipients present numerous problems of gastrintestinais that wich intefere with adequate oral intake. Previous studies showed the effectiveness of laminar air flow isolation, sterile diet, descontamination with oral antibiotcs and skin cleasing in prevention infections. The literature recommend the food sterilization by autoclave, irradiation or oven baking. This work purpose the microwave sterilization because it's a very quickly process, security and don't alter the flavour and aspect of food.
\end{abstract}

\section{INTRODUÇÃO}

A utilização de isolamento com fluxo laminar associado ao uso de antibióticos orais não absorvíveis, descontaminação da pele e dieta estéril tem resultado em uma redução significativa na incidência de infecções em pacientes receptores de transplante de medula ${ }^{1}$.

Observar-se que pacientes em uso de antibioticos orais não absorvíveis são também capazes de conseguir uma descontaminação gastrointestinal com alimentos de baixo nível de contaminação bacteriana, embora seja ideal, uma dieta esterril.

Âs infecções são desenvolvidas por bacilos gram-negativos que colonizam o trato gastrointestinal e respiratório e são a principal causa de morbidade e mortalidade.

$\mathrm{O}$ ambiente hospitalar incluindo o Serviço de $\mathrm{Nu}$ trição pode contribuir para a introdução de patógenos que são potencialmente virulentos e resistentes a antibióticos sistêmicos.

PIZZO et alii ${ }^{\circ}$ recomendam que a maioria dos alimentos enlatados que requerem aquecimento devem ser fervidos ou colocados no forno durante 5 minutos e transferidos a seguir para um recipiente estéril.

Outros alimentos podem ser colocados em placas estéreis, cobertos com papel alumínio e autoclavados a $121^{\circ} \mathrm{C}$, por 25 minutos.

Embora seja discutida a natureza exata do efeito biológico da radiação por microondas CULKIN \& FUNG $^{2}$ demonstraram que é possível. inativar culturas de Escherichia coli e Sabmonella typhimurion adicionadas a sopas de tomate, de vegetais e caldo de came quando submetidas à ação de microondas.

Estudos preliminares mostram que é possível inativar Bacillus subtilis, Enterobacter cloacea, Klebsiella pnewmonial, Serratia marcescens, Escherichia coli, Proteus mirabilis; Pseudomonas aeruginosa, Staphylo- cocus aureus, Staphylococus epidermidis por microondals, em 60 segundos.

Este trabalho tem por objetivo utilizar microondas a $2.450 \mathrm{MHz}$ como processo de esterilização de alimentos para pacientes submetidos a transplante de medula.

\section{MATERIAL E MÉTODOS}

Os alimentos utilizados para pesquisa foram coletados do Serviço de Nutrição e Dietética do Hospital das Clínicas da UFMG e fazem parte do cardápio do Hospital.

Os alimentos pesquisados foram sopa de feijão, sopra de macarrão com batatas, sopa de legumes, arroz, feijão, came moída, iscas de carnes, purê de batata baroa, beterraba e quiabo. De cada tipo de alimento, colocou-se $100 \mathrm{~g}$ em sacos plásticos próprios para microondas.

Cada saco plástico contendo o alimento foi colocado no centro do prato giratório de um forno de microondas e submetido à ação de microondas durante 2 minutos. A potência utilizada foi de 700 watts e a frequência de $2.450 \mathrm{MHz}$.

Com uma espátula estéril colheu-se $10 \mathrm{~g}$ de cada alimento que foi misturado em um Erlemeyer com 90 $\mathrm{ml}$ de Triptcase soy broth (TSB) e agitado durante 2 minutos.

Desta mistura, $2 \mathrm{ml}$ foi transferida por pipeta estéril para um tubo com 201 de TSB e mais $2 \mathrm{Ml}$ para 1 tubo com tioglicolato (T).

Com uma pipeta estéril transferiu-se $1 \mathrm{ml}$ da amostra para 1 placa de Petri estéril e adicionou-se $15 \mathrm{ml}$ de Triptcase soy agar (TSA).

A seguir, $50 \mathrm{ml}$ foi adequado por uma alça de platina em placas de agar sangue (AS). As placas com

\footnotetext{
* Professora Assistente da Escola de Enfermagem da UFMG. Mestre em Microbiologia.
} 
TSA forram incubadas a $37^{\circ} \mathrm{C}$ durante 48 horas e as placas com agar sangue foram incubadas em $5 \%$ de $\mathrm{CO}_{2}$ a $37^{\circ} \mathrm{C}$ durante 48 horas.

Os tubos de tioglicolato foram incubados a $37^{\circ} \mathrm{C}$ e os tubos de TSB à temperatura ambiente durante 5 dias. Após esse período, de cada cultura, foi plaqueado por alça de platina $50 \mathrm{ml}$ em agar sangue e incubado em $5 \%$ de $\mathrm{CO}_{2}, \mathrm{~s} 37^{\circ} \mathrm{c}$, durante $24 \mathrm{~h}$.

\section{RESULTADO E DISCUSSÃO}

Irradiação por microondas dos alimentos resultou esterelização dos mesmos dentro de $2 \mathrm{~min}$., de acordo com os dados apresentados na Tabela I.

\section{TABELA I - AVALIAÇÃO MICROBIOLÓGICA DE ALIMENTOS ESTERILIZADOS POR MICROONDAS EM 2 MINUTOS.}

\begin{tabular}{|c|c|c|c|c|c|c|}
\hline \multirow{2}{*}{ Tipos de Alimentos } & \multicolumn{6}{|c|}{ Meios de Cultura } \\
\hline & TSA & AS & TSB & $\mathrm{T}$ & $\begin{array}{l}\text { TSB } \\
\text { AS* }\end{array}$ & $\underset{\mathrm{AS}^{* *}}{\mathbf{T}}$ \\
\hline $\begin{array}{l}\text { - Sopa de Feijão } \\
\text { - Sopa de Macarrão } \\
\text { - Sopa de Legumes } \\
\text { - Arroz } \\
\text { - Feijão } \\
\text { - Carne Moída } \\
\text { - Iscas de Carne } \\
\text { - Purê de batata baroa } \\
\text { - Beterraba } \\
\text { - Quiaba }\end{array}$ & $\begin{array}{l}- \\
- \\
+ \\
- \\
- \\
- \\
- \\
+ \\
-\end{array}$ & $\begin{array}{l}- \\
- \\
- \\
- \\
- \\
- \\
- \\
- \\
-\end{array}$ & $\begin{array}{l}- \\
\overline{+} \\
- \\
- \\
- \\
- \\
- \\
-\end{array}$ & $\begin{array}{l}- \\
- \\
+ \\
- \\
- \\
- \\
- \\
- \\
-\end{array}$ & $\begin{array}{l}- \\
- \\
+ \\
- \\
- \\
+ \\
- \\
- \\
- \\
-\end{array}$ & $\begin{array}{l}+ \\
- \\
- \\
- \\
- \\
-\end{array}$ \\
\hline
\end{tabular}

* Cultura transferida do TSB para AS, com incubação em $5 \%$ de $\mathrm{CO}_{2}$

** Cultura transferida do Tioglicolato para AS, com incubação de $5 \%$ de $\mathrm{CO}_{2}$.

Ressalta-se que os sacos plásticos das amostras de sopa de legumes e sopa de macarrão romperam durante o processo de esterilização, por excesso de vapor formado no interior dos mesmos. Não houve contaminação da sopa de macarrão, mas as culturas da amostra de sopa de legumes apresentaram turvação nos tubos de TSB e T, e int́meras colónias na placa de TSA e AS apos transferencia da cultura de TSB. $O$ aspecto morfológico das colónias bem como o Gram revelaram tratar-se de contaminantes do ar.

As amostras de beterraba e iscas de carne apresentaram 1 e 2 colônias basterianas, respectivamente, também de contaminantes do ar.

O critério de tempo de esterilização por 2 minutos, foi baseado nos trabalhos de LATIMER \& MATSEN $^{5}$, que demonstraram que o tempo para inativar patôgenos comumente isolados em clínicas era de 60

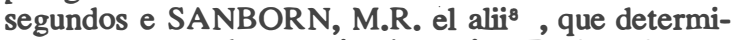
naram 60 segundos para inativar vírus Escherichia coli, Pseudomonas fluorescens, Klebsiella pneumoniae e 120 segundos para inativar Proteus vulgaris, Streptococus faecium, Corynebacterium equi e Bacillus globigii, embora estes autores tenham utilizado meios de cultura líquido com um volume de $5 \mathrm{ml}$.

Ainda $e$ incerto o mecanismo de morte de microorganismos por campo de rádio frequência ou microondas, mas a maioria dos autores acredita que o efeito letal é resultante do calor gerado, pois sabe-se que materiais que absorvem microondas convertem sua energia em calor.

Nestes experimentos verificou-se que a temperatura dos alimentos não foi além daquela alcançada por métodos convencionais de cozimento, e a morte bacteriana poderia ser explicada pelas alterações nas estruturas intracelulares produzidas pelo campo eletromagnético.
Microondas são geradas por um magnetron e propagadas em linha reta que é chamada de "modo dominante". Por causa disso a força do campo não é uniforme e aparece os "focos frios". Para contomar este problema colocou-se os pacotes de alimentos no centro do prato giratório.

Com dados obtidos pode-se concluir que é possível esterilizar alimentos por microondas.

\section{CONCLUSÃO}

A esterilização de alimentos por microondas é um método de economia de tempo e energia. É prático, seguro e não altera o sabor e aspecto dos alimentos, podendo contribuir sobremaneira para uma evolução satisfatória do paciente submetido ao transplante de medula. Por outro lado, facilita a aceitação da dieta pelo paciente cujos problemas gastrointestinais interferem em uma ingestão oral adequada.

Recomenda-se no entanto, definir a relação tempo de esterilização/volume do alimento e formas de acondicionamento dos mesmos.

\section{REFERÊNCIAS BIBLIOGRÁFICAS}

1 BUCKNER, D. et alii. Protective Environment for Marrow Transplant Recipients. Ann. Int. Med. 89: 893-901, 1978.

2 CULKIN, K.A., \& FUNG, D.Y.C. Destruction of Escherichia coli and Sallmonella Typhimurium in Microwave - cooked Soups. JMilk Food Technol. 38 (1): 8-15. 1975.

3 GOLDBLITH, S.A., \& WANG, D.I. Effects of Microwaves on Escherichia coli and Baullus subtilis. Appl. Microviol. 15: (6): 1371-5,1967.

4 GRONING, R., \& JANSKE, U. Keimzahbreduzierung durch Mikrowellen - mikrowellerispazifische effekte. Pharmazie. 42 (3): 167-8, 1987. 
5 LA TIMER, J.M., \& MA TSEN, J.M. Microwave Oven Irradiation as a Method for Bacterial Decontamination in a Clinical Microbiology Laboratory. J.Clin Microbiol. 6(4): 340-2, 1977.

6 PIZZO, P.A. et alii. Microbiological evaluation of food items.J.Am. Diet. Assoc. 81: 272-9, 1982.

7 ROHRER, M. \& BULARD, R.A. Microwave Sterilization
J.M.Diet Assoc. 110:194-8, 1985.

8 SANBORN, M.R. et alii. Microwave Sterilization of Plastic Tissue Cultura Vessels for Reuse. Appl. Env. Microbiol. 44 (4): 960-4, 1982.

9 YOUNG, S.K. GRA VES, D.C., ROHER, M.D., BULARD, R.A. Microwave Sterilization of nitrous oxide nasal hoods contamina ted with virus. Oral Surg. Oral Med.Pathol. 60 (6): 581-5, 1985. 